\title{
Glycogenolytic effects of the calcium ionophore A23187, but not of vasopressin or angiotensin, in foetal-rat hepatocytes
}

\author{
Michael FREEMARK and Stuart HANDWERGER \\ Department of Pediatrics, Duke University Medical Center, Durham, NC 27710, U.S.A.
}

(Received 19 December 1983/Accepted 15 February 1984)

\begin{abstract}
Vasopressin, angiotensin and phenylephrine stimulate glycogenolysis in postnatal rat liver by a $\mathrm{Ca}^{2+}$-mediated mechanism not involving cyclic AMP. To determine whether these hormones promote glycogenolysis in foetal liver, we have examined their effects, and those of the $\mathrm{Ca}^{2+}$ ionophore A23187, on glycogen metabolism in cultured foetal-rat hepatocytes. Vasopressin and angiotensin $(0.1 \mathrm{nM}-0.1 \mu \mathrm{M})$ had no effects on either glycogen synthesis (as assessed by $\left[{ }^{14} \mathrm{C}\right]$ glucose incorporation into glycogen) or phosphorylase $a$ activity. However, A23187 at 1 and $10 \mu \mathrm{M}$ inhibited glycogen synthesis by 31.3 and $89.1 \%$ respectively (both $P<0.001$ ) and stimulated phosphorylase $a$ activity by 66.9 and $184.1 \%$ respectively (both $P<0.01$ ). Incubation of cells in $\mathrm{Ca}^{2+}$-deficient medium attenuated the effects of $10 \mu \mathrm{M}-\mathrm{A} 23187$ on glycogen synthesis and abolished the effects of $1 \mu \mathrm{M}-\mathrm{A} 23187$. As in postnatal liver, glucagon (1 and $20 \mathrm{nM}$ ) and isoprenaline ( 1 and $10 \mu \mathrm{M})$, which activate adenylate cyclase, inhibited glycogen synthesis and stimulated phosphorylase $a$ activity in foetal hepatocytes. The minimal effective concentration of phenylephrine was 10 times that of isoprenaline. These results indicate striking differences in the ontogeny of cyclic AMP-mediated and $\mathrm{Ca}^{2+}$-mediated processes which regulate hepatic glycogenolysis. Since increases in cytosolic $\mathrm{Ca}^{2+}$ induce glycogenolysis in foetal-rat liver, the weak or absent responses to vasopressin, angiotensin and the $\alpha$-adrenergic agonists may result from defects in hormone-receptor binding or in post-receptor events leading to the mobilization of intracellular $\mathrm{Ca}^{2+}$ stores.
\end{abstract}

Hormones promote glycogenolysis in postnatal rat liver by at least two mechanisms. Glucagon and the $\beta$-adrenergic agonists bind to specific plasmamembrane receptors and activate adenylate cyclase. The consequent intracellular accumulation of cyclic AMP activates protein kinase and thereby initiates a cascade of protein phosphorylations which ultimately activates phosphorylase and inactivates glycogen synthase. $\alpha_{1}$-Adrenergic agonists, vasopressin, oxytocin and angiotensin, on the other hand, stimulate hepatic glycogenolysis and inhibit glycogen synthesis by a cyclic AMPindependent mechanism. The binding of these hormones to their respective plasma-membrane receptors is followed by the release of $\mathrm{Ca}^{2+}$ ions from intracellular stores and the elevation of cytosolic $\mathrm{Ca}^{2+}$ concentrations. These latter affects are associated with, and may be mediated by, hydrolysis of cellular phosphatidylinositol. The increase in cytosolic $\mathrm{Ca}^{2+}$ concentration in turn stimulates phosphorylase $b$ kinase and rapidly activates phosphorylase and inactivates glycogen synthase (Exton, 1979, 1980; Kirk et al., 1981; Blackmore et al., 1982; Creba et al., 1983; Litosch et al., 1983).

Whereas hepatocytes from juvenile rats respond equally well to both $\alpha_{1}$ - and $\beta$-adrenergic agonists (Blair et al., 1979), the effects of catecholamines on hepatocytes from adult male rats are mediated predominantly through $\alpha_{1}$-adrenergic receptors (Blair et al., 1979; Aggerbeck et al., 1980; Ichihara et al., 1982), and the adenylate cyclase response to adrenaline and isoprenaline is blunted (Bar \& Hahn, 1971; Christoffersen et al., 1973; Blair et al., 1979). In foetal-rat liver explants and cell cultures, on the other hand, the actions of adrenaline are mediated primarily via binding to $\beta$-receptors, suggesting that the $\mathrm{Ca}^{2+}$-mediated $\alpha_{1}$-adrenergic system may develop some time after birth (Sherline et al., 1974; Moncany \& Plas, 1980). To clarify further the role in foetal liver of hormones which promote glycogen degradation primarily via cyclic AMP-independent mechanisms, we have examined the effects of vasopressin, angiotensin and the 
$\mathrm{Ca}^{2+}$ ionophore $\mathrm{A} 23187$ on glycogen synthesis and phosphorylase $a$ activity in cultured foetal-rat hepatocytes.

\section{Materials and methods}

Vasopressin, angiotensin, dibutyryl cyclic AMP, (-)-isoprenaline, phenylephrine and cortisol were purchased from Sigma Chemical Co. (St. Louis, MO, U.S.A.). Ionophore A23187 (free acid) was purchased from Calbiochem Corp. (San Diego, CA, U.S.A.) and was dissolved in dimethyl sulphoxide immediately before use. Crystalline pig glucagon was obtained from Eli Lilly Co. (Indianapolis, IN, U.S.A.) and foetal bovine serum was purchased from Sterile Systems (Logan, UT, U.S.A.).

Foetal-rat hepatocytes were prepared as previously described (Freemark \& Handwerger, 1984). Briefly, Sprague-Dawley rats (Zivic Miller, Allison Park, PA, U.S.A.) on day 20 of gestation were killed and the foetuses were delivered rapidly by caesarean section. The foetal livers were removed aseptically, rinsed in a balanced salt solution $\{142 \mathrm{~mm}-\mathrm{NaCl} / 6.7 \mathrm{~mm}-\mathrm{KCl} / 10 \mathrm{~mm}$-Hepes [4-(2-hydroxyethyl)-1-piperazine-ethanesulphonic acid], pH 7.4 $\}$, and coarsely minced. The tissues were placed in trypsinizing flasks in a balanced salt solution containing $1 \mathrm{mM}$-EDTA and shaken at 80$90 \mathrm{rev} . / \mathrm{min}$ at $37^{\circ} \mathrm{C}$ for $15 \mathrm{~min}$. The suspension was centrifuged at $75 \mathrm{~g}$ for $4 \mathrm{~min}$ and the pellet was resuspended in a balanced salt solution containing $6.7 \mathrm{mM}-\mathrm{CaCl}_{2}$ and $0.5 \mathrm{mg}$ of collagenase (Worthington type I) $/ \mathrm{ml}$. The suspension was shaken at $80-90 \mathrm{rev} . / \mathrm{min}$ at $37^{\circ} \mathrm{C}$ for $15 \mathrm{~min}$ and then filtered through Nitex cloth $(150 \mu \mathrm{m}$ mesh $)$. The cells were then incubated with $0.001 \%$ deoxyribonuclease I (Worthington) at room temperature for $15 \mathrm{~min}$, and were re-filtered through Nitex. The cells were collected by centrifugation at $75 \mathrm{~g}$ for $5 \mathrm{~min}$ and washed three times with ice-cold balanced salt solution. Cell number was estimated in a haemocytometer, and viability, which exceeded $90 \%$ in all cases, was assessed by Trypan Blue exclusion. The cells were suspended in modified Eagle's minimal essential medium (Flow Laboratories, McLean, VA, U.S.A.) supplemented with $24 \mathrm{~mm}$ $\mathrm{NaHCO}_{3}, \quad 12.5 \mathrm{~mm}$-Hepes, $2 \mathrm{~mm}$-glutamine, $0.2 \mathrm{~mm}$-serine, $0.2 \mathrm{~mm}$-aspartate, $0.1 \mathrm{~mm}$-pyruvate, foetal bovine serum $(10 \%, \mathrm{v} / \mathrm{v}), 10 \mu \mathrm{M}$-cortisol, gentamycin $(50 \mu \mathrm{g} / \mathrm{ml})$ and amphotericin B $(5 \mu \mathrm{g} / \mathrm{ml})$ (supplemented MEM). The final concentration of glucose in supplemented MEM was $5.7 \mathrm{~mm}$. Approx. $4 \times 10^{6}$ cells in $2 \mathrm{ml}$ of medium were plated in $22.6 \mathrm{~mm}$-diameter non-collagencoated plastic culture dishes (Costar, Cambridge, MA, U.S.A.). Cultures were maintained at $37^{\circ} \mathrm{C}$ in an atmosphere of air/ $\mathrm{CO}_{2}(19: 1)$ and the medium was changed daily. Under these conditions, most of the haematopoietic cells, which do not attach to the culture dish, are removed, and the remaining cell population consists primarily $(70-85 \%)$ of clusters of hepatic parenchymal cells in monolayer.

Hormonal effects on the incorporation of $\left[{ }^{14} \mathrm{C}\right]-$ glucose into glycogen were measured under previously described conditions (Freemark \& Handwerger, 1984). On the third day of culture, the hepatocytes in supplemented MEM were exposed to hormone or diluent in the presence of $\mathrm{D}-\left[\mathrm{U}-{ }^{14} \mathrm{C}\right]-$ glucose (Amersham; $2.8 \mathrm{mCi} / \mathrm{mmol}, 0.5 \mu \mathrm{Ci} / \mathrm{ml}$ ). After a period of incubation at $37^{\circ} \mathrm{C}$, the medium was removed and the reaction terminated with icecold $0.03 \mathrm{M}-\mathrm{HCl}$. Radioactivity incorporated into glycogen was determined by the method of Chan \& Exton (1976).

To assess the effects of cellular $\mathrm{Ca}^{2+}$ depletion on the action of A23187, cell cultures were washed with warm $\mathrm{Ca}^{2+}$-free Krebs-Ringer bicarbonate buffer, $\mathrm{pH}$ 7.4. The cells were then incubated for $4 \mathrm{~h}$ with the same medium containing $2 \mathrm{mM}$-EGTA as well as A23187 or its diluent in the presence of $\left[{ }^{14} \mathrm{C}\right]$ glucose. Radioactive glycogen was purified and measured as described above.

Phosphorylase $a$ activity was measured in the direction of glycogen synthesis by a modification of the method of Golden et al. (1977). Preliminary experiments demonstrated that maximal stimulation of phosphorylase $a$ activity by glucagon occurred after 2-5 min of exposure to the hormone. Thus the effects of various hormones and agonists on phosphorylase $a$ activity were measured after a $4 \mathrm{~min}$ incubation period.

On the third day of culture, the hepatocytes in supplemented MEM were exposed to hormone or diluent for $4 \mathrm{~min}$. The incubation medium was then removed and the culture plates were rapidly frozen at $-70^{\circ} \mathrm{C}$. The cells were thawed at $4^{\circ} \mathrm{C}$ in the presence of a solution containing $50.0 \mathrm{mM}$ Tris/HCl, pH 7.4, $50 \mathrm{~mm}-\mathrm{NaF}, 10 \mathrm{~mm}$-EDTA, $0.5 \%$ glycogen and $5 \mathrm{~mm}$-dithiothreitol. The cells were scraped from the culture plates, sonicated for $20 \mathrm{~s}$ in an ice/water bath (Ultrasonics Inc., Plainview, NY, U.S.A.) and then centrifuged at $3000 \mathrm{~g}$ for $5 \mathrm{~min}$ at $4^{\circ} \mathrm{C}$. Then $50 \mu \mathrm{l}$ of the supernatant was incubated at $37^{\circ} \mathrm{C}$ for $15 \mathrm{~min}$ with $100 \mu \mathrm{l}$ of a solution containing $200 \mathrm{mM}-\mathrm{NaF}, 1.5 \%$ glycogen, $75 \mathrm{~mm}$-glucose 1-phosphate and $0.75 \mathrm{~mm}$-caffeine, pH6.2, with [U-14 C]glucose 1-phosphate $(200 \mathrm{Ci}$ / mol, $80000-100000$ c.p.m./100 $\mu \mathrm{l})$. At the end of the incubation period a sample of the reaction mixture was spotted on Whatman no. 3 filter paper, and the radioactive glycogen was measured by the method of Chan \& Exton (1976).

The data were normalized to the protein contents of the cell homogenates, which were determined by the method of Bradford (1976). In 
all experiments, the coefficients of variation for the responses to control and experimental treatments were less than or equal to $10 \%$. The statistical significance between sample means was tested by Student's $t$ test or by analysis of variance.

\section{Results}

As shown in Fig. 1 and Table 1, vasopressin and angiotensin $(0.1 \mathrm{nM}-0.1 \mu \mathrm{M})$ had no effects on either glycogen synthesis (as assessed by $\left[{ }^{14} \mathrm{C}\right]-$ glucose incorporation into glycogen) or phosphorylase $a$ activity. However, ionophore A23187 at 1 and $10 \mu \mathrm{M}$ inhibited glycogen synthesis by 31.3 and $89.1 \%$ respectively $(P<0.001$ in each instance), and stimulated phosphorylase $a$ activity by 66.9 and $184.1 \%$ respectively $(P<0.01$ in each instance). When cells were incubated in $\mathrm{Ca}^{2+}$. deficient medium, $1 \mu \mathrm{M}$-A23187 had no effect on glycogen synthesis and $10 \mu \mathrm{M}-\mathrm{A} 23187$ inhibited glycogen synthesis by only $38.1 \%$ (both $P<0.01$ ).

As shown in Table 2, glucagon ( 1 and $20 \mathrm{nM}$ ),

Table 1. Hormonal effects on phosphorylase a activity

Values represent the means \pm S.E.M. of results observed from four culture wells. Vasopressin and angiotensin also had no significant effects at concentrations of $0.1-10 \mathrm{nM}$. Similar results were obtained in each of three experiments. Abbreviation: NS, not significant.

\begin{tabular}{|c|c|c|c|}
\hline \multirow[b]{2}{*}{ Treatment } & \multicolumn{2}{|l|}{ Phosphorylase $a$ activity } & \multirow[b]{2}{*}{$P$ versus control } \\
\hline & $\begin{array}{l}\left(10^{-3} \times \text { c.p.m. of }\left[{ }^{14} \mathrm{C}\right] \text { glucose } 1 \text {-phosphate }\right. \\
\text { incorporated } 15 \mathrm{~min} \text { per } \mathrm{mg} \text { of protein })\end{array}$ & $\begin{array}{l}\text { Change from } \\
\text { control }(\%)\end{array}$ & \\
\hline $\begin{array}{l}\text { Control } \\
\text { Vasopressin }\end{array}$ & $13.5 \pm 0.9$ & & \\
\hline $\begin{array}{l}0.1 \mu \mathrm{M} \\
\text { Angiotensin }\end{array}$ & $14.0 \pm 1.1$ & +3.9 & NS \\
\hline $\begin{aligned} 0.1 \mu \mathrm{M} \\
\mathrm{A} 23187\end{aligned}$ & $12.6 \pm 1.2$ & -7.1 & NS \\
\hline $\begin{array}{c}0.1 \mu \mathrm{M} \\
1 \mu \mathrm{M} \\
10 \mu \mathrm{M} \\
\text { Glucagon }\end{array}$ & $\begin{array}{l}15.1 \pm 1.2 \\
22.6 \pm 1.4 \\
38.4 \pm 1.4\end{array}$ & $\begin{array}{r}+12.1 \\
+66.9 \\
+184.1\end{array}$ & $\begin{aligned} & N S \\
< & 0.01 \\
< & 0.001\end{aligned}$ \\
\hline $\begin{array}{c}1 \mathrm{nM} \\
20 \mathrm{nM} \\
(-) \text {-Isoprenaline }\end{array}$ & $\begin{array}{l}18.4 \pm 1.0 \\
22.3 \pm 0.9\end{array}$ & $\begin{array}{l}+36.4 \\
+65.2\end{array}$ & $\begin{array}{l}<0.01 \\
<0.01\end{array}$ \\
\hline $\begin{array}{l}1 \mu \mathrm{M} \\
10 \mu \mathrm{M} \\
\text { Phenylephrine }\end{array}$ & $\begin{array}{l}18.1 \pm 0.7 \\
25.2 \pm 1.1\end{array}$ & $\begin{array}{l}+34.2 \\
+86.4\end{array}$ & $\begin{array}{l}<0.01 \\
<0.005\end{array}$ \\
\hline $\begin{aligned} 1 \mu \mathrm{M} \\
10 \mu \mathrm{M}\end{aligned}$ & $\begin{array}{l}13.8 \pm 0.9 \\
17.2 \pm 0.9\end{array}$ & $\begin{array}{r}+2.0 \\
+27.6\end{array}$ & $\begin{array}{l}\text { NS } \\
<0.05\end{array}$ \\
\hline
\end{tabular}

Table 2. Hormonal effects on $\left[{ }^{14} \mathrm{Clglucose}\right.$ incorporation into glycogen

Values represent the means \pm S.E.M. of results obtained from four culture wells. Similar results were obtained in each of three experiments. Abbreviation: NS, not significant.

\begin{tabular}{|c|c|c|c|}
\hline \multirow[b]{2}{*}{ Treatment } & \multicolumn{2}{|c|}{$\left[{ }^{14} \mathrm{C}\right]$ Glucose incorporated } & \multirow[b]{2}{*}{$P$ versus control } \\
\hline & (nmol/mg of protein) & $\begin{array}{l}\text { Change from } \\
\text { control }(\%)\end{array}$ & \\
\hline $\begin{array}{l}\text { Control } \\
\text { Glucagon }\end{array}$ & $2.11 \pm 0.14$ & & \\
\hline $\begin{array}{l}1 \mathrm{nM} \\
20 \mathrm{~nm} \\
\text { Dibutyryl cyclic }\end{array}$ & $\begin{array}{l}1.48 \pm 0.13 \\
1.10 \pm 0.12\end{array}$ & $\begin{array}{l}-29.9 \\
-47.9\end{array}$ & $\begin{array}{l}<0.01 \\
<0.001\end{array}$ \\
\hline $\begin{array}{l}\text { Dibutyryl cyclic } \\
0.1 \mathrm{mM} \\
1 \mathrm{mM} \\
\text { (-)-Isoprenaline }\end{array}$ & $\begin{array}{l}1.59 \pm 0.11 \\
1.03 \pm 0.09\end{array}$ & $\begin{array}{l}-24.5 \\
-51.1\end{array}$ & $\begin{array}{l}<0.01 \\
<0.001\end{array}$ \\
\hline $\begin{array}{c}1 \mu \mathrm{M} \\
10 \mu \mathrm{M} \\
\text { Phenylephrine }\end{array}$ & $\begin{array}{l}1.56 \pm 0.10 \\
1.16 \pm 0.11\end{array}$ & $\begin{array}{l}-26.1 \\
-45.1\end{array}$ & $\begin{array}{l}<0.01 \\
<0.001\end{array}$ \\
\hline $\begin{array}{r}1 \mu \mathrm{M} \\
10 \mu \mathrm{M}\end{array}$ & $\begin{array}{l}2.05 \pm 0.15 \\
1.69 \pm 0.14\end{array}$ & $\begin{array}{r}-2.9 \\
-20.0\end{array}$ & $\begin{array}{c}\text { NS } \\
<0.05\end{array}$ \\
\hline
\end{tabular}

Vol. 220 


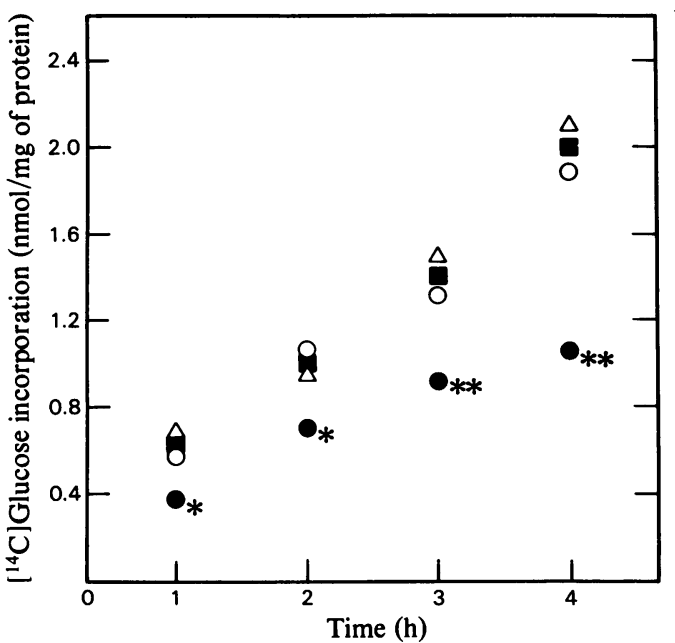

Fig. 1. Effects of $0.1 \mu \mathrm{M}$-vasopressin (O), $0.1 \mu \mathrm{M}$-angiotensin $(\triangle)$, InM-glucagon $(O)$ or diluent $(\square)$ on $\left[{ }^{14} C\right]-$ glucose incorporation into glycogen

Values represent the means of results obtained from four culture wells. In all cases, the S.E.M. was less than $5 \%$ of the mean value. Vasopressin and angiotensin also had no significant effects at concentrations of $0.1-10 \mathrm{nM}$. Similar results were obtained in each of three experiments. ${ }^{*} P<0.01$ and ${ }^{* *} P<0.001$, for homone-treated versus control.

dibutyryl cyclic AMP $(0.1$ and $1 \mathrm{mM})$ or isoprenaline (1 and $10 \mu \mathrm{M})$ each caused a dosedependent inhibition of glycogen synthesis. The minimal effective concentration of phenylephrine was 10 times that of isoprenaline. Glucagon at 1 and $20 \mathrm{~nm}$ stimulated phosphorylase $a$ activity by 36.4 and $65.2 \%$ respectively $(P<0.01$ in each instance): Isoprenaline at 1 and $10 \mu \mathrm{M}$ stimulated phosphorylase activity by 34.2 and $86.4 \%$ respectively $(P<0.01$ in each instance), whereas phenylephrine at $10 \mu \mathrm{M}$ stimulated phosphorylase activity by $27.6 \%(P<0.05)$. Phenylephrine at $1 \mu \mathrm{M}$ was without effect (Table 1).

\section{Discussion}

Although vasopressin and angiotensin in concentrations as low as $0.1 \mathrm{~nm}$ inhibit glycogen synthesis and activate phosphorylase in postnatal rat liver (Hems \& Whitton, 1980; Cantau et al., 1980; Wood et al., 1981; Creba et al., 1983), these hormones at 1000 -fold greater concentrations have no effects on glycogen metabolism in cultured foetal-rat hepatocytes. However, the ionophore A23187 inhibits glycogen synthesis and stimulates phosphorylase activation in foetal liver at concentrations comparable with those which induce glycogenolysis in postnatal rat liver (Strickland $e t$ al., 1980; Blackmore et al., 1982). Since the actions of A23187 are attenuated or abolished by cellular $\mathrm{Ca}^{2+}$ depletion, the ionophore effects in foetal liver, as in postnatal liver, appear to be mediated by increases in cytosolic free $\mathrm{Ca}^{2+}$. Since increases in cytosolic $\mathrm{Ca}^{2+}$ concentration induce glycogenolysis in foetal-rat hepatocytes, the failure of vasopressin and angiotensin to promote foetal hepatic glycogenolysis may result from a defect(s) in hormone-receptor binding and/or in postreceptor events leading to the mobilization of intracellular $\mathrm{Ca}^{2+}$ stores. Hepatic vasopressin receptors are barely detectable in the foetal rat and increase markedly in number during the second and third weeks after birth (Butlen et al., 1980). Therefore the developmental changes in the effects of vasopressin on foetal and postnatal liver glycogen metabolism may reflect the ontogeny of hepatic vasopressin receptors.

As in postnatal liver, glucagon and isoprenaline, which activate adenylate cyclase, inhibit glycogen synthesis and stimulate phosphorylase $a$ activity in foetal hepatocytes. The minimal concentration of phenylephrine that promotes glycogenolysis in foetal liver is 10 times that of isoprenaline. These studies indicate striking differences in the ontogeny of cyclic AMP-mediated and $\mathrm{Ca}^{2+}$-mediated processes which regulate hepatic glycogenolysis. These observations are consistent with previous findings, which suggested that catecholamine effects on foetal-liver glycogen metabolism are mediated through binding to $\beta$-adrenergic receptors (Sherline et al., 1974; Moncany \& Plas, 1980). Although $\alpha$-adrenergic receptors are detectable in homogenates of foetal rat liver (Butlen et al., 1980; McMillian et al., 1983), the cellular source (parenchymal or non-parenchymal) of these membrane binding sites is unknown. The predominance of $\beta$ adrenergic effects on foetal-liver glycogen metabolism may reflect the relatively high ratio of $\beta / \alpha_{1}-$ receptors in foetal liver (McMillian et al., 1983) and/or may result from a functional immaturity of the coupling of $\alpha_{1}$-receptor binding to one or more post-receptor events.

We thank Dr. J. J. Blum, Dr. A. J. Cohen, Dr. C. M. Kuhn and Dr. P. Zeitler for helpful comments and criticism, J. Williams and S. Jenkins for technical assistance and G. M. Kerr for secretarial assistance. This work was supported by National Institutes of Health grants HD07447 and HD06301.

\section{References}

Aggerbeck, M., Guellaen, G. \& Hanoune, J. (1980) Biochem. Pharmacol. 29, 643-645

Bar, H. P. \& Hahn, P. (1971) Can. J. Biochem. 49, 85-89

Blackmore, P. F., Hughes, B. P., Shuman, E. A. \& Exton, J. H. (1982) J. Biol. Chem. 257, 190-197

Blair, J. B., James, M. E. \& Foster, J. L. (1979) J. Biol. Chem. 254, 7579-7584 
Bradford, M. M. (1976) Anal. Biochem. 72, 248-254

Butlen, D., Guillon, G., Cantau, B. \& Jard, S. (1980) Mol. Cell. Endocrinol. 19, 275-289

Cantau, B., Keppens, S., DeWulf, H. \& Jard, S. (1980) J. Recept. Res. 1, 137-168

Chan, T. M. \& Exton, J. H. (1976) Anal. Biochem. 71, 96105

Christoffersen, T., Morland, J., Osnes, J. B. \& Oye, I. (1973) Biochim. Biophys. Acta 313, 338-349

Creba, J. A., Downes, C. P., Hawkins, P. T., Brewster, G., Michell, R. H. \& Kirk, C. J. (1983) Biochem. J. 212, 733-747

Exton, J. H. (1979) Biochem. Pharmacol. 28, 2237-2240

Exton, J. H. (1980) Am. J. Physiol. 238, E3-E12

Freemark, M. \& Handwerger, S. (1984) Am. J. Physiol. 246, E21-E24

Golden, S., Wals, P. A. \& Katz, J. (1977) Anal. Biochem. 77, 436-445
Hems, D. A. \& Whitton, P. D. (1980) Physiol. Rev. 60, 150

Ichihara, A., Nakamura, T. \& Tanaka, K. (1982) Mol. Cell. Biochem. 43, 145-160

Kirk, C. J., Michell, R. H. \& Hems, D. A. (1981) Biochem. J. 194, 155-165

Litosch, I., Lin, S.-H. \& Fain, J. H. (1983) J. Biol. Chem. 258, 13727-13732

McMillian, J. K., Schanberg, S. M. \& Kuhn, C. M. (1983) J. Pharmacol. Exp. Ther. 227, 181-186

Moncany, M. L. J. \& Plas, C. (1980) Endocrinology 107, 1667-1675

Sherline, P., Eisen, H. \& Glinsmann, W. (1974) Endocrinology 94, 935-939

Strickland, W. G., Blackmore, P. F. \& Exton, J. H. (1980) Diabetes 29, 617-622

Wood, C. L., Babcock, C. J. \& Blum, J. J. (1981) Proc. Soc. Exp. Biol. Med. 167, 129-136 